\title{
A High Sensitive Nested PCR for Toxoplasma gondii Detection in Animal and Food Samples
}

Maria Vitale $^{1 *}$, Paola Galluzzo ${ }^{1}$, Vittoria Currò ${ }^{1}$, Kataryna Gozdzik² ${ }^{2}$ Domenico Schillaci ${ }^{3}$ and Vincenzo Di Marco Lo Presti ${ }^{1}$

${ }^{1}$ Zooprofilactic Experimental Institute of Sicily (IZS Sicily), A. Mirri, via Gino Marinuzzi 3, Palermo 90129, Italy

${ }^{2}$ Witold Stefanski Institute of Parasitology of the Polish Academy of Sciences, 51/55 Twarda Street-00818, Warsaw, Poland

${ }^{3}$ Department of Biological, Chemical and Pharmaceutical Science and Technology (STEBICEF), University of Palermo, via Archirafi 32, Palermo 90123, Italy

\begin{abstract}
Toxoplasma gondii is a major food and waterborne transmitted parasite world-wide. The tissues and meat samples of many warm blooded animals can contain tissues cysts from chronic toxoplasmosis. Water and vegetable can be contaminated by the parasitic oocysts shed through the feces of infected cats, representing the definitive host of the parasite.

A sensitive PCR for Toxoplasma gondii detection is described. The first step amplified the region between the $28 \mathrm{~S}$ and $18 \mathrm{~S}$ rDNA in the closely related $T$. gondii and Neospora caninum; RFLP analysis distinguished the DNA from the two morphologically identical parasites. Although N. caninum is not involved in human transmission, so far, it is important for animal health since is a major responsible for abortion in cattle.

The nested PCR was used in a dilution assay in pork sausage samples spiked with $T$. gondii parasitic DNA. The analysis showed that up to $200 \mathrm{fg}$ equivalent to two single parasites only, could be detected. Similar detection limit for $T$. gondii can be obtained with real-time PCRs, but real time methods need special consumables and expensive equipment.
\end{abstract}

Keywords: Neospora caninum; Toxoplasma gondii; Restriction fragments length polymorphism; Nested PCR

\section{Introduction}

Toxoplasma gondii is a coccidian protozoan that can infect different tissues in several warm blooded animals and toxoplasmosis is the most diffused food and waterborne parasitic infection worldwide [1]. The serological screening for T. gondii reveal high positive level in livestock and the presence of tissue cysts in meat is an important risk factor for toxoplasmosis transmission. The infection is quite often mild or asymptomatic in immune-competent individuals but can be particularly severe in immune-compromised subjects. Furthermore T. gondii is implicated in abortion cases in several animal species. Congenital toxoplasmosis (the vertical transmission from the mother to the fetus) is a big concern in public health for the potential severe outcomes for the baby [2]. The consumption of undercooked or raw meat is a main risk factor for toxoplasma infection in human beings, as established by multicenter study [3]. However, several typical cuisines include dishes based on raw meat preparation in many countries and these traditional practices can be difficult to change despite educational campaigns [4].

In this paper, a nested PCR targeting the ribosomal DNA locus is described. The ribosomal locus in T. gondii is represented by a 7.5$\mathrm{kb}$ rDNA unit arranged in head-to-tail tandem repeats of at least 110 copies per haploid tachyzoite genome [5]. The sensitivity was evaluated using spiked fresh pork sausage.

\section{Material and Methods}

T. gondii DNA was extracted from the reference strain Me49 provided by the European Parasite Reference Laboratory at the National Institute of Health in Rome.

N. caninum DNA was obtained from tachyzoites of Polish bovine isolate $\mathrm{NcPolB} 1$ and from a reference strain $\mathrm{NC1}$ maintained at the Witold Stefanski Institute of Parasitology, Warsaw [6].
The analysis on fresh prepared pork sausage was set-up as follows: a sample of $5 \mathrm{~g}$ of the sausage was suspended in $5 \mathrm{ml}$ TRIS-EDTA and homogenized by EDTS VIII homogenizer (Design Village Ltd, U.K.). A positive suspension was prepared by adding an aliquot of $10 \mu \mathrm{l}$ of a DNA solution at concentration of $1 \mathrm{ng} / \mu \mathrm{l}$ to a volume of aliquot of 190 $\mu \mathrm{l}$ of the sausage homogenate. Four serial dilutions of 1 to 10 up to 1 pg of DNA followed by two further dilutions 1 to 5 to a final amount of $0.04 \mathrm{pg}$ were prepared. The DNA was extracted from the homogenates by Gene Elute mammalian kit (cat $\mathrm{N}^{\circ}$ G1N350Sigma-Aldrich St. Louis, $\mathrm{MO}, \mathrm{USA}$ ) following manufacturer's instructions.

\section{First PCR and RFLP analysis}

Common primers for T. gondii and the related parasite N. caninum NC 18S RNA sense primer 5' TGCGGAAGGATCATTCACACG 3' and NC28SRNA antisenseprimers 5'CCGTTACTAAGGGAATCATAGTT 3 ' where used for the first PCR. The digestion with endonucleases Hinf I (Promega Madison, WI, USA) of the first amplification product was performed with DNA extracted from the parasite. After first PCR, an aliquot of $5 \mu \mathrm{l}$ of the PCR reaction was digested in $50 \mu \mathrm{l}$ of final volume in $1 \mathrm{X}$ enzyme buffer at $37^{\circ} \mathrm{C}$ for 1 hour. The digested products were loaded on $2 \%$ agarose gel containing ethidium bromide and visualized on CHEMI-DOC image-analyser (Biorad, Hercules, CA 94547 USA).

*Corresponding author: Maria Vitale, Zooprofilactic Experimental Institute of Sicily (IZS Sicily), A. Mirri, via Gino Marinuzzi 3, Palermo 90129, Italy, E-mail: marvitus@yahoo.com

Received February 19, 2013; Accepted March 14, 2013; Published March 18 2013

Citation: Vitale M, Galluzzo P, Currò V Gozdzik K, Schillaci D, et al. (2013) A High Sensitive Nested PCR for Toxoplasma gondii Detection in Animal and Food Samples. J Microb Biochem Technol 5: 039-041. doi:10.4172/1948-5948.1000097

Copyright: ( 2013 Vitale M, et al. This is an open-access article distributed under the terms of the Creative Commons Attribution License, which permits unrestricted use, distribution, and reproduction in any medium, provided the original author and source are credited 
For the nested PCR, $1 \mu \mathrm{l}$ after the first cycle, was amplified with T. gondii specific primers Toxo ITS1sense 5' GATTTGCATTCAAGAAGC(G)TGATAGTAT 3'Toxo ITS1 antisense 5’ AGTT(T)AGGAAGCAATCTGAAAGCACATC 3' [7].

Both PCR reactions were performed on $50 \mu \mathrm{l}$ of $50 \mathrm{mM} \mathrm{KCl}$, $1.5 \mathrm{mM} \mathrm{MgCl}, 20 \mathrm{mM}$ Tris-66 $\mathrm{HCl}(\mathrm{pH} 8.4), 100 \mu \mathrm{M}$ (each) dATP, dTTP, dCTP, and dGTP, 50 pmol of primers, and $3 \mathrm{U}$ of Taq gold DNA polymerase (Applied Biosystem, Life Technologies Corporation) with the following PCR program: $10 \mathrm{~min}$ at $95^{\circ} \mathrm{C}$ and then 40 cycles of $50 \mathrm{~s}$ at $94^{\circ} \mathrm{C}, 30 \mathrm{~s}$ at $60^{\circ} \mathrm{C}, 1 \mathrm{~min}$. at $72^{\circ} \mathrm{C}$ and a final extension of $7 \mathrm{~min}$ at $72^{\circ} \mathrm{C}$ in a 9700 thermal cycler (Applied Biosystem Life Technologies Corporation)

\section{Results and Discussion}

The PCR primers used for the first PCR were chosen in a conserved region of the rRNA locus of the two similar parasites $N$. caninum and T. gondii. An amplicon of almost $1000 \mathrm{bp}$ is obtained after first amplification spanning the intergenic region included between $18 \mathrm{~S}$ and $28 \mathrm{~S}$ of the rRNA locus. The morphologically identical oocysts of N.caninum and T. gondii can be distinguished by Restriction Fragments Length Polymorphism (RFLP) analyses upon digestion with restriction enzymes. After the restriction with Hinf I, a doublet of 500 bp is present in T. gondii and three fragments in N. caninum (Figure 1). A comparison of the same region in gene bank database showed that all T. gondii and N. caninum isolates sequenced so far have the same Hinf I restriction map respectively and different RFLP can be also observed using other frequent cutter enzymes like RsaI and AluI.

The two parasites are so closely related and morphological identical that N. caninum was misdiagnosed as T. gondii until 1988 when its identity and life cycle were discovered [8]. N. caninum has a narrower host spectrum and it is not implicated in zoonosis but is important in animal health because it is a major cause of abortion in cattle [9]. Toxoplasmosis on the contrary is the most diffused parasitic zoonosis in the world. Nested PCR, increasing both specificity and sensitivity of the analysis, can be used to screen animal tissues and meat samples such as milk, meat, vegetables, for the presence of the parasitic DNA. The described nested PCR was set on spiked pork sausage because several human acute toxoplasmosis cases in Italy are suspected to be related to this meat preparation. As established by a questionnaire administration, the very common practice to taste raw fresh sausage might be responsible of many cases of acute toxoplasmosis. To evaluate the sensitivity of the method, pork sausage homogenates was spiked with T. gondii DNA and a series of dilutions of 1:10 were performed starting from $1000 \mathrm{pg}$ to $1 \mathrm{pg}$ (lane 1 to 4 of figure 2) followed by two dilutions 1:5 up to $40 \mathrm{fg}$ of DNA (lanes 5 and 6). The DNA could be detected in the nested step up to $200 \mathrm{fg}$ (lane 5) and no amplification with $N$. caninum DNA was observed (lane 8). The detected amount is equivalent to two parasites with a comparable sensitivity shown in the real-time PCR assay described by Jauregui et al. [7]. Many end-point and real time PCRs have been evaluated for Toxoplasmosis diagnosis so far, but still a unique standardized method is not available $[10,11]$. Direct comparisons among different methods have shown that the performance of the results depend upon a lot of variables such as the copies number of the DNA template and the type of clinical specimen (blood versus CSF or amniotic liquid) [12,13]. It has also been reported a nested PCR method that had a higher sensitivity compared to two real-time PCRs which allowed a more rapid identification of $T$. gondii DNA but showed some discrepancies in a minority of routine samples from immune-compromised patients [14]. A commercial nested PCR,

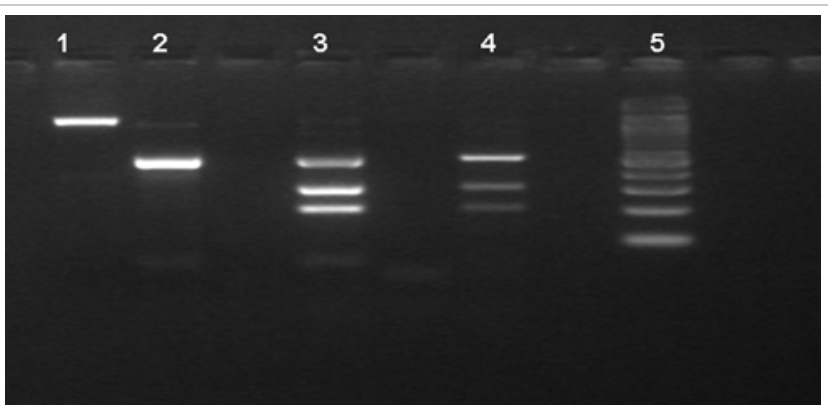

Figure 1: First PCR amplicon of 1000 bp was digested with Hinf I for 1 hour at $37^{\circ} \mathrm{C}$ and run on $1.5 \%$ agarose gel.

RFLP pattern on first PCR-amplicons from Toxoplasma gondii and Neospora caninum isolates after digestion with Hinf I.

Lane 1: undigested $1 \mathrm{~kb}$ amplicon of $T$. gondii.

Lane 2: T. gondii me 49, first PCR amplicon digested: the pattern shows a doublet of $500 \mathrm{pb}$ which is indicative of one recognition site for Hinf I.

Lanes 3: digestion pattern in the amplicon of $N$. caninum PolB1 isolate [6] Lane 4: digestion pattern in the amplicon of NC1 reference strain [6]

Both DNAs show DNA fragments of $500 \mathrm{bp}, 300 \mathrm{bp}$ and $200 \mathrm{bp}$, revealing the presence of two recognition sites

Lane 5: DNA size marker 100 bp ladder

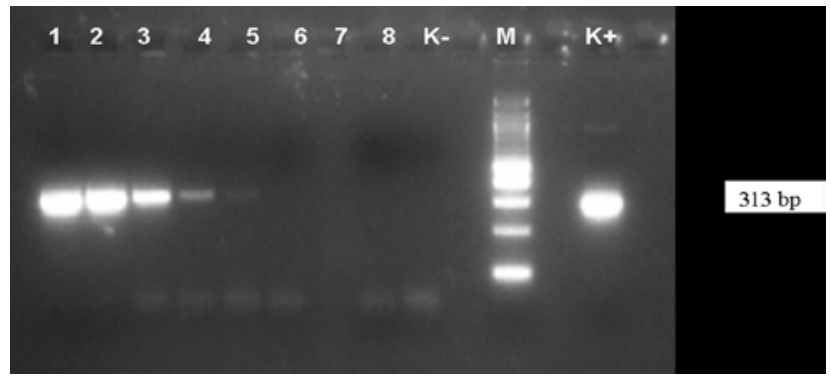

Figure 2: Nested PCR assay with fresh pork sausage samples spiked with $T$. gondii DNA at different concentrations expressed in picograms (pg) and femtograms (fg). $T$ gondii specific primers amplify a region of $313 \mathrm{bp}$ in the intergenic region 1 (ITS1) of the parasite ribosomal RNA operon [7] internal to the first amplicon.

Lane $1-1000 \mathrm{pg}$

Lane $2-100 \mathrm{pg}$

Lane 3-10 pg

Lane 4-1 pg

Lane $5-200 \mathrm{fg}$

Lane $6-40 \mathrm{fg}$

Lane 7-empty

Lane 8-PCR with Neospora DNA (NC1)

$\mathrm{K}$-: PCR mix with no template

$\mathrm{K}+$ : PCR mix plus $T$. gondii DNA from strain Me49.

The DNA could be detected up to $200 \mathrm{fg}$ corresponding to two parasites (lane 5). The amplicon of $313 \mathrm{bp}$ is pointed by the arrow.

approved for T. gondii analysis in human clinical specimens, has been evaluated for analytical performance and economic impact with two different real-time methods. The analytical performance showed that one real-time method was more sensitive whereas the other real time and nested PCR had the same sensitivity. In terms of economic impact, the commercial nested PCR used by the authors, resulted more expansive in consumables compared to the two real-time PCRs; however nested PCR was still recommended for small laboratories that process few clinical samples per year because of the high cost of the real time equipment [13]. Several nested PCRs for other infectious diseases are often reported to have similar analytical performance to real- 
Citation: Vitale M, Galluzzo P, Currò V, Gozdzik K, Schillaci D, et al. (2013) A High Sensitive Nested PCR for Toxoplasma gondii Detection in Animal and Food Samples. J Microb Biochem Technol 5: 039-041. doi:10.4172/1948-5948.1000097

time PCRs that require higher cost for equipment and consumables $[15,16]$. The described in house nested PCR in our hands is cheaper in consumables and has the advantages to permit: i) the distinction between $N$. caninum and T. gondii oocysts which is important in veterinary medicine and ii) the screening of food samples by a high sensitive method with no need for expensive equipment. Although the nested PCR is more time and work consuming with a higher possibility of sample contamination, it is easily performed in many laboratories in the veterinary field and in developing countries where budget constraints are important.

\section{Acknowledgments}

The authors thank Dr. Maria Anna La Giglia for her scientific contribution. The study was funded by Italian Ministry of Health: grant N ${ }^{\circ}$ RF-2007 and RC 2009 to Vitale M.

\section{References}

1. Jones JL, Dubey JP (2010) Waterborne toxoplasmosis--recent developments. Exp Parasitol 124: 10-25.

2. Dubey JP (2010) Toxoplasmosis of animals and humans. CRC Press, Boca Raton, FL.

3. Cook AJ, Gilbert RE, Buffolano W, Zufferey J, Petersen E, et al. (2000) Sources of toxoplasma infection in pregnant women: European multicentre case-contro study. European Research Network on Congenital Toxoplasmosis. BMJ 321: 142-147.

4. Vitale M, Di Marco Lo Presti V (2013) Food Safety or Typical Dishes? Toxoplasma gondii and Educational Preventive Campaign. Foodborne Pathog Dis 10: 196.

5. Guay JM, Huot A, Gagnon S, Tremblay A, Levesque RC (1992) Physical and genetic mapping of cloned ribosomal DNA from Toxoplasma gondii: primary and secondary structure of the $5 S$ gene. Gene 114: 165-171.
6. Goździk K Cabaj W (2007) Characterization of the first Polish isolate of Neospora caninum from cattle. ActaParasitol 52: 295-297.

7. Jauregui LH, Higgins J, Zarlenga D, Dubey JP, Lunney JK (2001) Development of a real-time PCR assay for detection of Toxoplasma gondii in pig and mouse tissues. J Clin Microbiol 39: 2065-2071.

8. Dubey JP, Carpenter JL, Speer CA, Topper MJ, Uggla A (1988) Newly recognized fatal protozoan disease of dogs. J Am Vet Med Assoc 192: 1269 1285

9. Dubey JP, Schares G, Ortega-Mora L (2007) Epidemiology and control of neosporosis and Neospora caninum. ClinMicrobiol Rev 20: 323-367.

10. Bastien P (2002) Molecular diagnosis of toxoplasmosis. Trans R Soc Trop Med Hyg 96 Suppl 1:S205-215.

11. Switaj K, Master A, Skrzypczak M, Zaborowski P (2005) Recent trends in molecular diagnostics for Toxoplasma gondii infections. Clin Microbiol Infect 11: $170-176$

12. Reischl U, Bretagne S, Krüger D, Ernault $P$, Costa JM (2003) Comparison of two DNA targets for the diagnosis of Toxoplasmosis by real-time PCR using fluorescence resonance energy transfer hybridization probes. BMC Infect Dis 3: 7 .

13. Calderaro A, Piccolo G, Gorrini C, Peruzzi S, Zerbini L, et al. (2006) Comparison between two real-time PCR assays and a nested-PCR for the detection of Toxoplasma gondii. Acta Biomed 77: 75-80.

14. Hierl T, Reischl U, Lang P, Hebart H, Stark M, et al. (2004) Preliminary evaluation of one conventional nested and two real-time PCR assays for the detection of Toxoplasma gondii in immunocompromised patients. J Med Microbiol 53: 629-632.

15. Drago L, Lombardi A, De Vecchi E, Giuliani G, Bartolone R, et al. (2004) Comparison of nested PCR and real time PCR of Herpesvirus infections of central nervous system in HIV patients. BMC Infect Dis 4: 55.

16. Bastien P, Procop GW, Reischl U (2008) Quantitative real-time PCR is not more sensitive than "conventional" PCR. J Clin Microbiol 46: 1897-1900. 